\title{
ISLAMIC PHILANTHROPY AND THE THIRD SECTOR: THE PORTRAIT OF ZAKAT ORGANIZATIONS IN INDONESIA
}

\author{
D. Muht ada \\ Department of Political Science, Northern Illinois University, \\ DeKalb, USA \\ dmuhtada@niu.edu
}

\begin{abstract}
This paper discusses the role of zakat organizations as the emerging Third Sector in Indonesia. It presents the profiles of three currently leading zakat organizations: Rumah Zakat Indonesia (RZI), Dompet Dhuafa (DD), and Pos Keadilan Peduli Ummat (PKPU). This paper highlights that the zakat organizations play an important role in serving public needs in Indonesia. They offer many services in such areas as health, economy, education, agriculture, and disaster reliefs. Competition does exist among zakat organizations, particularly if they operate in the same areas and target the same segment of donors (e.g., wealthy Muslims in urban areas). This paper argues that some more efforts are still needed to strengthen the roles of zakat organizations as part of the Indonesian third sector. This could be achieved through strengthening the accountability and the transparency of zakat management as well as by encouraging zakat organizations to allocate more funds for economic development programs. Allocating more funds for economic development programs would make zakat organizations more powerful in promoting social welfare in the society.
\end{abstract}

Keywords: Islamic Philanthropy; Third Sector; Zakat Organizations; Indonesia

\section{INTRODUCTION}

A zakat organization is a philanthropic organization that collects, manages, and distributes zakat funds among Muslim societies. Zakat is the concept of alms and tithing in Islam. This religious teaching plays an important role in motivating philanthropic activities in Muslim societies. The teaching encourages Muslims to pay a certain proportion of their wealth for the benefits of specified categories of people called mustahiqs. However, it is 
not compulsory for Muslims to pay zakat through a certain zakat organization. They may give their zakat directly to the poor and the needy.

In Indonesia, the practice of zakat shows an increase trend, reflected on the increasing number of zakat organizations after 1998. This trend also reflects an increasing need for a specific institution that is responsible for organizing zakat funds among Indonesian Muslim societies. At least 250 zakat organizations had been registered with the members of Forum Organisasi Zakat (FOZ), which is an association of Indonesian zakat organizations (Forum Zakat). ${ }^{1}$ Most of these organizations are run by Muslim communities and a few of them are run by government agencies. These organizations conduct philanthropic activities, in which they raise, manage, and distribute zakat funds for the purposes of social welfare.

The objective of this paper is to analyze the role of philanthropic organizations as part of the third sector in Indonesia. The role of zakat organizations will be a focus of this study since these philanthropic organizations have emerged as the strong third sector in Indonesia after the fall of Suharto in 1998. To begin with, the paper discusses the theoretical framework of philanthropy and the third sector. Here, the concepts of philanthropy and the third sector are discussed. Second, the paper provides a brief explanation about zakat and zakat organizations in Muslim societies. This section explores the teaching of zakat as a concept of philanthropy in Islam. It also explores the general picture of zakat organizations in Muslim societies. Third, the paper discusses the role of zakat organizations as part of the third sector in Indonesia. The discussion includes the development of zakat organizations in modern Indonesia, the competition for resources among them, and their contributions to the Indonesian communities. An analysis on how zakat organizations can be developed to strengthen their roles as part of the third sector is provided at the end.

\section{MATERIALS AND METHODS}

In order to discuss the above issues, this paper uses socio-theological approaches. This is because zakat is basically a theological issue which is posited as the third of five pillars of Islam. Through theological approach this paper will show that zakat in Islamic doctrine is of high significance as well as in social life. It is to the latter position that social approach will be applied. This is to say that social activities conducted through zakat funds will be analyzed to see the social significance of this pillar of Islam. Meanwhile, the data used to analyze the issues under discussion consist of those that are available online at the zakat organization websites. In addition, the data were also obtained from the relevant writings on the discussed issues.

${ }^{1}$ http://forumzakat.net (retrieved May 20, 2010). 


\section{RESULT AND DISCUSSION}

\section{A. Philanthropy and the Third Sector: A Discourse}

The word "philanthropy" literally means "the love of mankind." ${ }^{2}$ However, Washburn indicates that this concept has been transformed over the years, so that today's philanthropic activities do not have to be connoted with loving the objects of the philanthropic activities. Jones ${ }^{3}$ argues that the term philanthropy may be understood differently. A person can regard his or her work as philanthropic, but the others may consider it as the right thing to do. Thus, different people may define the word differently. Jones himself defines the word philanthropy as "a desire to help mankind, especially as shown by gifts to charitable or humanitarian institutions; benevolence." Ross $^{4}$ denotes the term 'philanthropy' to an action of giving something without expecting any personal return. Payton ${ }^{5}$ provides both a narrower and a broader definition of philanthropy. By a narrower meaning, the word refers to "voluntary, one-way transfer of exchangeable." By a broader definition, the word "philanthropy' refers to "having or showing interest in or being concerned with the welfare of others."

Philanthropy in this paper refers to the act of donating something to help people or improve the quality of human lives regardless of any personal return. Philanthropic organizations refer to charitable or humanitarian institutions that collect and manage donations to help people and or improve the quality of people's lives.

Like the definition of philanthropy, the definition of the third sector also varies. Hemment ${ }^{6}$ describes the third sector as a domain of informal groups such as associations and non-governmental organizations. The word 'third' is attached to make it different from the state (i.e., the first), and the private sector of business and enterprises (i.e., the second). Lohmann ${ }^{7}$ mentions another definition, which is according to him common in thirdsector studies, that is "a cluster of tax-exempt and tax-deductible organizations that together constitute civil society and contrasted with 'market' and 'state' organizations". Some claim that "the third sector" is just "civil society" that includes only non-political organizations, to differ

\footnotetext{
${ }^{2}$ W.E. Washburn, "Philanthropy and the American Indian: The Need for a Model," Ethnohistory, 15: 1 (1968): 43-56; R.A. Lohmann, "Charity, Philanthropy, Public Service, or Enterprise: What Are the Big Questions of Non-profit Management Today?" Public Administration Review, 67: 3 (2007): 437-444.

${ }^{3}$ E.M. Jones, "Building a Future Worthy of Our Past," Foundation: News \& Commentary, 46: 4 (2005) (retrieved from http://www.foundationnews.org/CME/articles.cfm?ID=110\&IssueID=3333, May 8, 2010).

${ }^{4}$ A.D. Ross, "Organized Philanthropy in an Urban Community," The Canadian Journal of Economics and Political Science, 18: 4 (1952): 474-486.

${ }^{5}$ R.L. Payton, "Philanthropic Values," Philanthropy: Private Means, Public Ends, ed. K. W. Thompson (New York: University Press of America, 1987) (retrieved from http://webstorage3.mcpa.virginia.edu/publications/mcpapers/rhetoric4.pdf, February 6, 2010).

${ }^{6}$ J. Hemment, 'The Riddle of the Third Sector: Civil Society, International Aid, and NGOs in Russia," Anthropological Quarterly, 77: 2 (2004): 215-241.

${ }^{7}$ Lohmann, "Charity, Philanthropy, Public Service, or Enterprise," 440.
} 
it from the power structures (the first sector) and business (the second sector). ${ }^{8}$ Such a claim is rejected by Couto, ${ }^{9}$ who argues that the third sector is not equivalent to civil society and that not all third sector organizations are civil society organizations. According to him, civil society is a social domain that enables and stimulates citizen participation and supremacy. Quoting O'Connell, Couto mentions five important parts of civil society: the individual, the community, voluntary associations, business, and government. This definition includes government and business as parts of civil society. Since government and business have been widely considered as the first and the second sector respectively, ${ }^{10}$ civil society is not necessarily equivalent to the third sector.

Gidron et. al. ${ }^{11}$ describe a more specific definition of the third sector. According to them, the third sector organizations are those that are formal organizations, nonprofit distributing, private, independent (i.e., having mechanism of self-rule), and voluntary (i.e., having philanthropic inputs - that is, giving and volunteering and voluntary membership). Such a definition is similar to another definition given by Ranci, ${ }^{12}$ which says that the third sector is a collection of independent institutions that have two things in common: (1) they are organized not for profit, and (2) they aim at serving the public interest. Examples of these institutions include nursing homes established by religious groups, hospitals and universities managed by private foundations, and networks of volunteers supporting patients in public hospitals.

The term "third sector" in this paper refers to the definition of the third sector as defined by Gidron et al and Ranci. It refers to organizations that are non-profit and voluntary. They are private and independent, but should be differentiated from the private sector, which refers to profitmaking organizations. The third sector is basically non-governmental organizations that are organized to serve public interests. Philanthropic organizations, including religious organizations which are charitable or humanitarian, are included in this definition of the third sector.

Nowadays, philanthropic organizations are among the important components of the third sector in many countries. In Canada, before the twentieth century, philanthropic activities remained unplanned and accidental. As a result, only a few people made donation for religious, health, or educational motives, and the distribution was just limited for the

\footnotetext{
${ }^{8}$ L. Alekseyeva, "The 'Third Sector' and the Authorities," Social Sciences, 34: 3 (2003): 122-128.

9 R.A. Couto, "The Third Sector and Civil Society: The Case of the 'YES' Campaign in Northern Ireland," Voluntas: International Journal of Voluntary and Nonprofit Organizations, 12: 3 (2001): 221-238.

${ }^{10}$ Hemment, "The Riddle of the Third Sector," 215-241; Lohmann, "Charity, Philanthropy, Public Service, or Enterprise," 437-444; Alekseyeva, "The 'Third Sector' and the Authorities," 122-128. 20-59.

${ }^{11}$ B. Gidron, et. al., "Through a New Lens: The Third Sector and Israeli Society," Israel Studies, 8: 1 (2003):

${ }^{12}$ C. Ranci, "Democracy at Work: Social Participation and the 'Third Sector' in Italy," Daedalus, 130: 3 (2001): 73-84.
} 
needy. ${ }^{13}$ Since the twentieth century, organized philanthropic activities involving a large numbers of volunteers have been run to collect donations. The funds are managed and distributed for various purposes. The same trend happened in the USA. Pierce ${ }^{14}$ highlights the role of the Young Men's Christian Association (YMCA) as a pioneer of modern philanthropic organization in the early $1900 \mathrm{~s}$. These facts confirm what Washburn ${ }^{15}$ indicates as the transformation of the concept of philanthropy from a sense of personal piety to an institutionalized charity. Instead of doing philanthropic activities individually, people started to organize philanthropic activities with a clear set of visions, missions, and objectives.

Considering the advance development of philanthropic organizations in the twentieth century, the study by Wolpert and Reiner ${ }^{16}$ on philanthropy 'marketplace' is important to note. In this study, Wolpert and Reiner discuss the context of interaction between donor and recipient. This includes why people donate their funds to certain institutions instead of the others. The study identifies several types of donors in terms of their giving motivation and donation behaviors (Table 1).

Table 1

Typology of Donors

\begin{tabular}{|c|l|l|}
\hline No. & \multicolumn{1}{|c|}{ Type } & \multicolumn{1}{c|}{ Explanation } \\
\hline 1 & The 'user' donors & $\begin{array}{l}\text { They take advantage directly of the contribution as a } \\
\text { consumer of the service which is subsidized by the } \\
\text { donations }\end{array}$ \\
\hline 2 & $\begin{array}{l}\text { The 'subsidizer' } \\
\text { donors }\end{array}$ & $\begin{array}{l}\text { They donate to enhance the consumption of services by } \\
\text { others }\end{array}$ \\
\hline 3 & The 'civic' donors & $\begin{array}{l}\text { They sponsor programs to improve the community and } \\
\text { its image }\end{array}$ \\
\hline 4 & The 'patron' donors & $\begin{array}{l}\text { They provide benefaction and protection to endangered } \\
\text { service or activity to obtain reputation }\end{array}$ \\
\hline 5 & The 'prestige' donors & $\begin{array}{l}\text { They donate openly to advance themselves economically } \\
\text { or socially }\end{array}$ \\
\hline 6 & $\begin{array}{l}\text { The 'deduction' } \\
\text { donors }\end{array}$ & $\begin{array}{l}\text { They give contribution consistent with the price of } \\
\text { donating }\end{array}$ \\
\hline 7 & $\begin{array}{l}\text { The 'compensation' } \\
\text { donors }\end{array}$ & $\begin{array}{l}\text { They expect, through their donation, to return to their } \\
\text { community a token of benefits they have enjoyed }\end{array}$ \\
\hline 8 & $\begin{array}{l}\text { The 'obligation' } \\
\text { donors }\end{array}$ & $\begin{array}{l}\text { They donate when they feel obliged by appeal or } \\
\text { pressure }\end{array}$ \\
\hline 9 & $\begin{array}{l}\text { The 'exchange' } \\
\text { donors }\end{array}$ & $\begin{array}{l}\text { They are willing to support some secondary activities or } \\
\text { services in return for others' support of their primary } \\
\text { cause }\end{array}$ \\
\hline 10 & $\begin{array}{l}\text { The 'religious' } \\
\text { donors }\end{array}$ & $\begin{array}{l}\text { They accept the traditional command and teaching on } \\
\text { helping the less fort unate }\end{array}$ \\
\hline
\end{tabular}

\footnotetext{
${ }^{13}$ Ross, "Organized Philanthropy in an Urban Community," 474-486.

${ }^{14}$ L.L. Pierce, "Philanthropy - A Major Big Business," The Public Opinion Quarterly, 2: 1 (1938): 140-15.

${ }^{15}$ Washburn, "Philanthropy and the American Indian," 43-56.

${ }^{16}$ J. Wolpert and T. Reiner, "The Philanthropy Marketplace," Economic Geography, 60: 3 (1984): 197-209.
} 


\begin{tabular}{|c|l|l|}
\hline 11 & $\begin{array}{l}\text { The 'example' } \\
\text { donors }\end{array}$ & They donate so that others wish to act similarly \\
\hline 12 & The 'crisis' donors & $\begin{array}{l}\text { They contribute only when disaster occurs and need is } \\
\text { memorable }\end{array}$ \\
\hline 13 & The 'dollar' donors & $\begin{array}{l}\text { They gives a modest amount whenever asked because } \\
\text { they are reluctant to refuse }\end{array}$ \\
\hline 14 & The 'Kantian' donors & $\begin{array}{l}\text { They benefit only from the giving and not directly or } \\
\text { indirectly from the use of donation }\end{array}$ \\
\hline
\end{tabular}

(Source: Wolpert \& Reiner, 1984)

Although various motives may stimulate donors to give their funds, religion still plays significant role in stimulating philanthropic activities. The success story of YMCA in the United States, ${ }^{17}$ which was a religiousaffiliated group, indicates this significance. Research conducted by Berger ${ }^{18}$ on the influence of religion on philanthropy in Canada indicates that religious affiliation and self-perceived religiosity influence significantly on promoting philanthropic activities. As indicated by this study, the most philanthropic people are those who identify themselves as conservative Protestant, while the least philanthropic are those who are not affiliated with any religion. No wonder, Payton ${ }^{19}$ argues that "religion is the most influential private stimulus in international philanthropy".

\section{B. Zakat Organizations: An Overview}

Zakat is one of five Islamic pillars (arkān al-Isläm). It literally means purity, growth, and full of goodness. ${ }^{20}$ Even though it is an Arabic word, a study by Bashear ${ }^{21}$ on cognate words from the vocabulary of other religions shows that the word might be borrowed from Jewish lexicon. This argument is supported by a fact that several Quranic verses that order the performance of zakat (Quran, 2: 43, 83 and 110) actually address the Children of Israel.

In Islamic legal theory, zakat means a religious duty incumbent upon Muslims to give a certain amount of their wealth to recipients under specific conditions. There are two kinds of zakat: (1) zakāt al-fitr and (2) zakàt al-māl. The first one (zakāt al-fițr) is an obligation of every Muslim, except those who are completely destitute, to donate a small amount of

\footnotetext{
${ }^{17}$ Pierce, "Philanthropy - A Major Big Business," 140-145; Ross, "Organized Philanthropy in an Urban Community," 474-486.

${ }^{18}$ I. E. Berger, "The Influence of Religion on Philanthropy in Canada," Voluntas: International Journal of Voluntary and Nonprofit Organizations, 17: 2 (2006): 115-132.

${ }^{19}$ Payton, "Philanthropic Values."

${ }^{20}$ A. Salim, The Shift in Zakat Practice in Indonesia: From Piety to an Islamic Socio-Political-Economic System (Chiang Mai: Silkworm Books, 2008); J. Benthall, "Financial Worship: The Quranic Injunction to Almsgiving," The Journal of the Royal Anthropological Institute, 5: 1 (1999): 27-42; T. Kuran, "The Economic system in Contemporary Islamic Thought: Interpretation and Assessment," International Journal of Middle East Studies, 18: 2 (1986): 135-164.

${ }^{21}$ S. Bashear, "On the Origins and Development of the Meaning of Zakat in Early Islam," Arabica, 40 (1993): 84-113.
} 
food or money at the end of Ramadan (the month of fasting). The second one (i.e., zakāt al-māl) is a portion of wealth that a Muslim should pay, under certain conditions and requirements, whenever his or her wealth has reached the nisāa - that is, a fixed amount of value upon which zakat is due. ${ }^{22}$ As one of the Islamic five pillars, zakat has been one of the most important teachings in Islam. The Quran stresses zakat as part of the faith. Several Quranic verses illustrate the practice of zakat as part of the virtues of the true believer (Quran, 13: 22; 35: 29). Monzer Kahf ${ }^{23}$ argues that zakat is actually a transfer of wealth and income from the haves to the have-nots to establish socio-economic justice. The teaching of zakat promotes the idea of socio-economic justice and a fair distribution of wealth in society. It prevents the concentration of wealth in the hands of a few rich persons (Quran, 59: 7).

Although zakat is an obligation, it is not compulsory to pay zakat through a zakat organization. Muslims may give their zakat directly to the needy or the poor. However, the payment of zakat through a zakat organization has at least four advantages. First, zakat can be managed more professionally. Zakat institutions can make such efforts as social and economic mapping, surveys, and systematic empowerment planning so that zakat funds can be managed and distributed more efficiently and effectively. Second, the existence of a zakat institution enables a zakat payer to pay the zakat more easily. For example, some zakat organizations in Indonesia such as Dompet Dhuafa and LAZIS Muhammadiyah offer payment facilities through internet banking and short-message-service (SMS). Third, the poor and the needy know where to go when they need zakat funds. Fourth, the management of zakat by a zakat organization requires accountability and transparency, which need for things like annual reports, an independent audit, and feedback from the public. These processes will ensure that the distribution of zakat is managed according to the interests of society.

Y üsuf Al-Qaradāwi $\bar{i}^{24}$ argues that state involvement in the establishment of a zakat institution is needed because it will assure that the religious obligation is enforced. However, this state involvement is not without disadvantages. This is particularly obvious when monopoly in the management of zakat by the state exists. The absence of competition in the collection and distribution of zakat may negatively affect the performance of the state's zakat agency (e.g., transparency, accountability, professionalism). On the contrary, zakat management by the third sector,

\footnotetext{
${ }^{22}$ Alfitri, "The Law of Zakat Management and Non-governmental Zakat Collectors in Indonesia," The International Journal of Not-for-Profit Law, 8: 2 (2006).

${ }^{23}$ Monzer Kahf, "Islamic Banks at the Threshold of the Third Millennium," Thunderbird International Business Review, 41: 4-5 (1999): 445-460.

${ }^{24}$ Yūsuf al-Qaradāwī, Fiqh al-Zakah, vol. 2, trans. Monzer Kahf (Jeddah: King Abdul Aziz University, 2007) (retrieved from http://monzer.kahf.com/books/english/fiqhalzakah_vol2.pdf, February 6, 2010).
} 
not by state, has advantages. One of the advantages is that donors can choose zakat organizations through which they will channel their funds. This encourages competition among zakat organizations, so that they are motivated to improve their performances.

Some experiences of zakat organizations around the world illustrate the significant roles of these organizations as part of the third sector to provide social services. These organizations work to aid people and or improve the quality of people's lives. In the United States, a zakat organization called Zakat Foundation of America introduces programs such as healthcare, emergency relief, orphan sponsorship, and Muslim-American scholarships. It also runs some overseas development programs such as micro-credit for developing countries. ${ }^{25}$ In Australia, a zakat organization called Human Appeal International collect zakat and other donations to run social programs such as income generation for poor families, educational projects and medical projects. It also provides safe water for underprivileged communities. It has an orphan sponsorship project that is designed to help disadvantaged orphans in Australia and overseas. ${ }^{26}$

In Indonesia, although some local governments have established zakat agencies called Badan Amil Zakat Infaq Sedekah (BAZIS), many Muslim communities and groups established their own zakat organizations. Among the leading zakat organizations run by Indonesian Muslim societies are Rumah Zakat Indonesia (RZI), Pos Keadilan Peduli Ummat (PKPU), and Dompet Duafa (DD). These organizations play significant roles in collecting and distributing zakat in society. The total annual funds collected by Rumah Zakat Indonesia in 2008 reached nearly IDR 70 billion (US\$ 7 million). ${ }^{27}$ In the same year, the total annual funds collected by Pos Keadilan Peduli Ummat (PKPU) reached IDR 45 billion (US\$ 5 million). This indicates that these zakat institutions got a high trust from society. The following section will discuss the role of non-governmental zakat organizations as part of the third sector in Indonesia.

\section{Zakat Organizations in Indonesia}

\section{Zakat Organization: Profiles of the Third Sector}

As parts of the third sector, the history of zakat organizations is relatively new to Indonesian society. A study by $\mathrm{Salim}^{28}$ indicates that the third sector in Indonesia started to organize zakat in the second half of the Suharto government. Zakat organizations established by Muslim community organizations such as Dompet Duafa and Yayasan Dana Sosial Al-Falah began to emerge in 1990s. Before this time, there were zakat

\footnotetext{
${ }^{25} \mathrm{http}: / /$ www.zakat.org (retrieved May 20, 2010).

${ }^{26} \mathrm{http}: / /$ www.humanappeal.org.au (retrieved May 20, 2010).

${ }^{27} \mathrm{http}: / /$ www.rumahzakat.org (retrieved May 20, 2010).

28 A. Salim, "The Influential Legacy of Dutch Islamic Policy on the Formation of Zakat (alms) Law in Modern Indonesia," Pacific Rim Law \& Policy Journal, 15: 3 (2006): 683-701.
} 
agencies established by some provincial governments. These zakat agencies were called Badan Amil Zakat, Infaq, dan Sedekah (BAZIS). In the Sukarno era (1945-1966), there were no zakat organizations established by government agencies. At this time, zakat was traditionally collected and distributed by religious figures (e.g., kyai, modin, or Quranic teachers).

Zakat organizations started to emerge as the strong third sector after the fall of Suharto (1998). This was a result of more freedom of expression, the reform of government regulations on non-profit sector organizations, and the impacts of a regional monetary crisis that hit Indonesia in 1997. The post-Suharto government provided incentives for non-profit organizations such as giving them tax deductions or exemption. In the case of zakat organizations, two regulations should be mentioned - that is, the Law No. 38/1999 on Zakat Fund Management and the Law No. 17/2000 on the new regulations on income tax. The first law allows the existence of zakat organizations run by communities and grants them authorities to collect zakat funds. The second law introduced two significant changes concerning zakat: 1) zakat is no longer the object of tax; and 2) zakat can reduce taxable income. This law implies the government support for the existence of zakat organizations in Indonesia and encourages more people to pay zakat. ${ }^{29}$ As a result, the number of zakat organizations increased significantly from 150 in 1999 to 250 in $2006 .{ }^{30}$ Among these organizations are three leading zakat organizations: Dompet Dhuafa (DD), Rumah Zakat Indonesia (RZI), and Pos Keadilan Peduli Ummat (PKPU), which will be the examples of the third sector to be discussed more deeply in this paper.

Dompet Dhuafa (DD) is one of the pioneers of zakat agencies sponsored by a Muslim community. It was established by several journalists of Republika (Jakarta-based newspapers) in July 1993. The establishment of DD was inspired by the journalists' day-to-day interaction with the urban poor in Jakarta. They were concerned with social and economic gaps between the rich and the poor in the city. The journalists first started to collect zakat among them and distributed the funds to the needy spontaneously and sporadically. The journalists then established DD in order to manage zakat funds more professionally. They started to collect zakat from the general public and to manage the funds under the principles of modern management. ${ }^{31}$ DD's programs include education and training, health services, community development, micro-financing, and disaster

${ }^{29}$ E. Syamsulhakim, "The Effect of the Implementation of the New Regulation on Personal Income Taxation in Indonesia (the Law Number 17/2000) on the Behavioral of Personal Income Tax and Islamic Income Tithe (zakāt al-māl) Payer," Working Paper in Economics and Development Studies, Department of Economics, Padjadjaran University, Bandung, Indonesia http://www.equitablepolicy.org/wpaper/200202.pdf, May 20, 2010).

${ }^{30} \mathrm{http}: / / \mathrm{www}$.forumzakat.net (retrieved May 20, 2010).

${ }^{31} \mathrm{http}: / / w w w . d o m p e t d h u a f a . o r . i d(r e t r i e v e d ~ M a y ~ 20,2010)$. 
relief. $^{32}$ In 2001, DD established a health clinic called Layanan Kesehatan Cuma-Cuma (LKC), which offered free health service for the poor. This LKC also offers mobile health services and covers wider areas in the Jakarta sub-urban areas. In 2007, DD established a hospital to provide better health services for the needy. More than 200 thousand poor have been registered as the members of this hospital and have enjoyed its free health services.

Rumah Zakat Indonesia (RZI) is another leading zakat agency in Indonesia. It was established in Bandung in 1998 by a small Islamic group called Ummul Qura. At the beginning, RZI focused its programs on trauma relief among the victims of social conflicts in Ambon and North Maluku (East Indonesia). However, in 2000, it developed such programs as the urban poor development, economic empowerment, health services, and scholarships for orphans and children from poor families. It also launched a program called "free ambulance service" by which the poor can use it for funeral or emergency situations. To attract potential donors, RZI shows the public their programs and achievements. It produces brochures, bulletins, and billboards which highlight the professionalism of zakat management. It posts boxes in such strategic places as malls, banks, hospitals and government offices so that people can easily donate their money. As of 2010, RZI had 45 branch offices throughout the country. ${ }^{33}$

While the establishment of RZI was inspired by social conflicts, the establishment of Pos Keadilan Peduli Ummat (PKPU) was inspired by the impacts of the Asian monetary crisis that hit the Indonesian economy in 1997. A group of Muslim youths established PKPU in December 1999 to help the poor deal with the impacts of the monetary crisis. They not only focused on economic development, but also on education and the rehabilitation of public facilities. They also work for social conflicts and disaster relief. As of 2007, PKPU has expanded its branches to 16 provinces of Indonesia and almost all of the main islands including Java, Sumatera, Kalimantan, Sulawesi and Maluku islands. ${ }^{34}$

\section{Distribution of Resources and Competition}

As far as resource distribution is concerned, zakat organizations have contributed significantly to public services in Indonesia. As parts of the third sector, zakat organizations offer many services in such areas as health, economy, education, agriculture, and disaster reliefs. The RZI's 2010 annual report shows that this zakat organization had developed economic programs for 5,671 people, had provided scholarships for 21,668 children from poor families, had provided health services for 17,476 patients. ${ }^{35}$ As of

${ }^{32}$ The Synergos Institute, National Directory of Civil Society Resource Organizations: Indonesia (retrieved from http://www.synergos.org/knowledge/02/indonesiacsrodirectory.pdf, May 20, 2010).

${ }_{33}^{33} \mathrm{http}: / /$ www.rumahzakat.org (retrieved May 20, 2010).

${ }^{34} \mathrm{http}: / /$ www.pkpu.or.id (retrieved May 20, 2010).

${ }^{35} \mathrm{http}: / /$ www.rumahzakat.org (retrieved May 20, 2010). 
December 2007, PKPU provided health services for at least 196,615 patients in 11 provinces, built four medical centers, provided health insurance for 79,624 people, build 396 permanent houses for poor families, and had 4,821 volunteers to work on natural disaster relief. ${ }^{36}$ DD gave health vouchers to more than 40 thousand poor families, so they got access to free health services provided by DD's clinics and hospitals. ${ }^{37}$ The total number of these organization's clients might be relatively small compared to the total number of Indonesians living under poverty line, which reached $17 \%$ of 228 million people in $2008 .{ }^{38}$ However, there are more than 250 zakat organizations throughout country. These organizations typically have programs similar to those managed by the three zakat organizations (i.e., RZI, PKPU, and DD). Therefore, the existences of zakat organizations as part of the third sector in Indonesia are not insignificant.

One question is how efficient and effective these zakat organizations manage their resources. Although the measurements of organizational performance in non-profit organizations might be different from those in profit organizations, ${ }^{39}$ zakat organizations can evaluate their efficiency and effectiveness in the distribution of resources by using such techniques as cost benefit analysis, economic impact analysis, modeling, and opinion and client satisfaction surveys. ${ }^{40}$ Another way to measure the efficiency is by using ethical control so the staffs are aware of their actions, consider carefully their environments, and do their bests to achieve organizational goals. RZI has introduced organizational principles, which functions as ethical control for organizational members. The principles include six important things: trustworthiness, professionalism, client convenience, synergy, accuracy in distribution, and clarity of report. ${ }^{41} \mathrm{DD}$ has a similar ethical control called "DD's Moral Principles", which includes integrity, trustworthiness and benevolence. DD also introduces the standards of organizational performance called "DD's Principles of Institutional Existence". These principles include transparency, accountability, professionalism, efficiency and effectiveness, and continuous self-evaluation. ${ }^{42}$ $20,2010)$

${ }^{36} \mathrm{http}: / /$ www.pkpu.or.id (retrieved May 20, 2010).

${ }^{37} \mathrm{http}: / /$ www.dompetdhuafa.or.id (retrieved May 20, 2010).

${ }^{38}$ World Bank, Indonesia at a Glance (retrieved from http://devdata.worldbank.org/AAG/idn_aag.pdf, May

${ }^{39}$ K. McMullen and G. Schellenberg, “Job Quality in Non-profit Organizations', CPRN Research Series on Human Resources in the Non-profit Sector, 2 (2003) (retrieved from http://www.eric.ed.gov/ERICDocs/data/ericdocs2sq1/content_storage_01/0000019b/80/1b/20/c1.pdf, February 6, 2010).

${ }^{40}$ B. Carin and D.A. Good, "Evaluating efficiency and effectiveness in public sector delivery," a paper prepared as part of the CEPRA project on Sector and Regional Specifics of Reformation of Budgetary Institutions for the Kaliningrad Workshop, July 24-25 (2004) (retrieved from http://www.aucc.ca/_pdf/english/programs/cepra/Evaluation_Paper.pdf, February 6, 2010)

${ }^{41} \mathrm{http}: / /$ www.rumahzakat.org (retrieved May 20, 2010).

${ }^{42} \mathrm{http} / / / w w w . d o m p e t d h u a f a . o r . i d(r e t r i e v e d ~ M a y ~ 20,2010)$. 
To promote transparency and accountability, RZI provides unique usernames and passwords for its donors, by which they can check the history of personal donation trough the RZI's website. RZI also provides facilities on its website so that all stakeholders could give their feedback to improve the organization's performance. Online staffs are available to respond to visitors' enquiries. Stakeholders can also call or text the RZI's staff for enquiries. Website visitors may receive regular newsletters via email if they subscribe their email addresses on the website. RZI also makes its annual financial report available on the website. ${ }^{43}$ Two other zakat organizations (PKPU and DD) also provide similar facilities on their websites to indicate transparency and accountability.

It is important to note that these three zakat organizations exist in a highly competitive environment among many other zakat organizations. Competition becomes tougher for these three zakat organizations, among themselves or with other zakat organizations, because they often operate in the same areas. RZI has branch offices in Jakarta, Bandung, Semarang, Surabaya, and Banda Aceh, and so does PKPU. ${ }^{44}$ Moreover, these organizations often target the same segment of donors - that is, wealthy Muslims in urban areas.

Such a highly competitive environment is also experienced by zakat agencies that have strong attachments to particular Islamic organizations. The examples of these zakat agencies are LAZIS NU and LAZIS Muhammadiyah. These zakat organizations belong to two biggest Islamic organizations in Indonesia: Nahdlatul Ulama (NU) and Muhammadiyah. NU claims to have 40 million members, while Muhammadiyah claims to have 30 million members. NU and Muhammadiyah may mobilize their members to pay their zakat through their own zakat agencies. However, such a mobilization does not always work because the members of NU and Muhammadiyah do not always feel obliged to pay their zakat through their organizations. Their religious teaching tells them that they can pay zakat through any zakat organizations or give the money directly to the recipients (e.g., the poor, the needy, mosques, etc.). In addition, because of their strong relationships with their umbrella organizations, the independencies of LAZIS NU and LAZIS Muhammadiyah are questionable. For instance, although NU and Muhammadiyah are not political parties, some key figures of these organizations have been involved in political parties. For example, Hasyim Muzadi, who was a former chairperson of NU, was one of the candidates running for the vice president position in the 2004 election. Amien Rais, who was a former chairperson of Muhammadiyah, is currently one of the influential figures in a political party called Partai Amanat Nasional (PAN). This question of organizational independency does not

\footnotetext{
${ }^{43} \mathrm{http}: / /$ www.rumahzakat.org (retrieved May 20, 2010).

${ }^{44} \mathrm{http}: / /$ www.rumahzakat.org (retrieved May 20, 2010); http://www.pkpu.or.id (retrieved May 20, 2010).
} 
really bother similar zakat organizations that have no attachments to particular Islamic groups or political parties such as DD, YDSF, and Dompet Ummat.

\section{Zakat Organization: Towards A Stronger Third Sector} Since zakat organizations contribute significantly to serve public needs, it is important to strengthen their roles as part of the third sector in Indonesia. At least two things need further consideration: the legal aspects of zakat organizations and economic empowerment programs.

As far as the legal aspect is concerned, the Indonesian government has enacted the Law No. 38/1999 on Zakat Management. The law allows the establishment of zakat organizations by Muslim communities. This law brings a significant change in the history of zakat management in Indonesia. In the era of Sukarno (1945-1966), the government did not establish a zakat agency and did not grant any legal status for a zakat institution in Muslim societies. As a matter of fact, during this era, there was no specific organization that was responsible for managing zakat funds among societies. ${ }^{45}$ In the era of Suharto (1966-1998), some provincial and local governments established zakat agencies. Yet, the government did not recognize any legal organization to collect and to distribute zakat funds from Muslim societies. Today, the government allows the third sector to collect, manage, and distribute zakat funds. The existence of zakat organizations is acknowledged legally by the government. The Law No. $38 / 1999$ results in a significant increase in the number of zakat organizations. However, the Law does not clearly regulate aspects on organizational accountability and transparency. There is no special state agency that is responsible for monitoring and supervising the operations of these zakat organizations. This weakness has been a central point of critique of this Law by the public.

The introduction of the new zakat law (Law No. 23/2011) on the zakat management responded to the needs for a better monitoring and supervision of the zakat administration in Indonesia. For example, it is mentioned in the Article 29 of the Law that the district governmentsponsored zakat organization (Baznas Kabupaten/Kota) should provide a regular report to the Baznas at the provincial level as well as to their respective heads of district (regents or mayors). Meanwhile, the Provincial Baznas should provide the same regular report to the national BAZNAS as well as to their respective governors. In addition, the 2011 Law on zakat management also provides a stronger sanction for an abuse of zakat management and administration. In the old law on zakat, the sanction is given to any zakat organizer who does not record or makes false records

${ }^{45}$ Salim, “The Influential Legacy of Dutch Islamic Policy," 683-701. 
about the collection and the distribution of zakat. These violators could receive a maximum three-month sentence and or a maximum fine of IDR 3 million. In the new 2011 law, sanctions are made stronger. The law states that the violators could receive a maximum five-year sentence and or a maximum fine of IDR 500 million. It is expected that by designing a stronger punishment for a poor zakat management, the 2011 new law on zakat would lead to the betterment of zakat administration in Indonesia.

As far as the economic program is concerned, zakat organizations need to allocate more funds for economic development. Many zakat organizers in Indonesia state that they work to promote social and economic justice. PKPU, for example, states in its organizational vision and missions that the organization is designed to improve the community's welfare. ${ }^{46} \mathrm{DD}$ states in its organizational vision and missions that they will manage zakat to empower society through entrepreneurship. ${ }^{47}$ A similar statement can also be found in the vision and mission of RZI ${ }^{48}$ However, the portion of zakat funds allocated for economic development programs within these organizations is still relatively small compared to that allocated for other programs. RZI, for instance, only spent around 1.3\% of total expenditures in 2008 (IDR 478 million of IDR 37.4 billion) for economic development programs. ${ }^{49}$ PKPU spent $6.27 \%$ of total expenditure for economic partnerships in 2008 - that is, IDR 2.05 billion of IDR 32.7 billion (Pos Keadilan Peduli Ummat). DD shows a better proportion of total funds spent for economic programs compared to that of RZI and PKPU. In 2008 , this organization allocated $57 \%$ of total zakat funds for economic development programs (dana bergulir) - that is, IDR 2 billion of IDR 3 billion. In the future, zakat organizations will need to allocate more money for economic development programs, so that zakat management can be a strong instrument to promote social and economic welfare in society.

Table 2

Zakat Fund Allocated for Economic Development by Zakat Organizations in 2008

\begin{tabular}{|l|l|l|c|}
\hline \multicolumn{1}{|c|}{$\begin{array}{c}\text { Zakat } \\
\text { Organizations }\end{array}$} & Mission Statements & \multicolumn{1}{|c|}{$\begin{array}{c}\text { Economic } \\
\text { Development } \\
\text { Programs }\end{array}$} & $\begin{array}{c}\text { Budget } \\
\text { Percentages }\end{array}$ \\
\hline $\begin{array}{l}\text { Pos Keadilan } \\
\text { Peduli Ummat } \\
\text { PKPU) }\end{array}$ & $\begin{array}{l}\text { The organization is } \\
\text { designed to improve the } \\
\text { community's welfare }\end{array}$ & $\begin{array}{l}\text { Community } \\
\text { empowerment program }\end{array}$ & $6.27 \%$ \\
\hline $\begin{array}{l}\text { Dompet Dhuafa } \\
\text { (DD) }\end{array}$ & $\begin{array}{l}\text { The organization } \\
\text { manages zakat to } \\
\text { empower society through } \\
\text { entrepreneurship }\end{array}$ & $\begin{array}{l}\text { Peasant Empowerment } \\
\text { Program, Community } \\
\text { Development Program, } \\
\text { Microfinance Program }\end{array}$ & $57 \%$ \\
\hline
\end{tabular}

\footnotetext{
${ }^{46} \mathrm{http}$ ://www.pkpu.or.id (retrieved May 20, 2010).

${ }^{47} \mathrm{http}: / /$ www.dompetdhuafa.or.id (retrieved May 20, 2010).

${ }^{48} \mathrm{http}: / /$ www.rumahzakat.org (retrieved May 20, 2010).

${ }^{49} \mathrm{http}: / /$ www.rumahzakat.org (retrieved May 20, 2010).
} 


\begin{tabular}{|l|l|l|c|}
\hline $\begin{array}{l}\text { Rumah Zakat } \\
\text { Indonesia (RZI) }\end{array}$ & $\begin{array}{l}\text { Developing the economic } \\
\text { independency of society } \\
\text { through productive } \\
\text { economic empowerment }\end{array}$ & Interest free loans & $1.3 \%$ \\
\hline
\end{tabular}

\section{CONCLUSION}

As parts of the third sector, zakat organizations play an important role in serving public needs in Indonesia. Zakat organizations started to emerge as the strong third sector after the fall of Suharto (1998). This was a result of three conditions: a more freedom of expression, the reform of government regulations on non-profit sector organizations, and the impacts of regional monetary crisis that hit Indonesia in 1997. As parts of the third sector, zakat organizations offer many services in such areas as health, economy, education, agriculture, and disaster reliefs. They help the government serve public needs for society.

Competition does exist among zakat organizations, particularly if they operate in the same areas and target the same segment of donors (e.g., wealthy Muslims in urban areas). Zakat organizations that have strong attachments to particular Islamic organizations such as NU and Muhammadiyah still experience such a high competitive environment. LAZIS NU and LAZIS Muhammadiyah are organized by two largest Islamic organizations in Indonesia: Nahdlatul Ulama (NU) and Muhammadiyah. These Islamic organizations could mobilize their members to pay their zakat through their own zakat agencies. However, such a mobilization does not always work because the members of NU and Muhammadiyah do not always feel obliged to pay their zakat through their organizations. Unfortunately, because of their strong relationships with their umbrella organizations, the independencies of NU and Muhammadiyah's zakat organizations are politically questionable. As a result, donors would be less interested in giving their money to these zakat organizations than to zakat organizations that have no attachments to political movements (e.g., DD, RZI, YDSF, Dompet Ummat).

Since zakat organizations contribute significantly to serve public needs, it is important to strengthen their roles as part of the third sector in Indonesia. This could be achieve, for example, through strengthening the accountability and the transparency of zakat management as well as by encouraging zakat organizations to allocate more funds for economic development programs. Allocating more funds for economic development programs would make zakat organizations more powerful in promoting social welfare in the society. 


\section{REFERENCES}

Alekseyeva, L. "The 'Third Sector' and the Authorities," Social Sciences, 34: 3 (2003): 122-128.

Alfitri. "The Law of Zakat Management and Non-governmental Zakat Collectors in Indonesia," The International Journal of Not-for-Profit Law, 8: 2 (2006).

Al-Qaraḍāwì, Yūsuf. Fiqh al-Zakah, trans. Monzer Kahf, vol. 2. Jeddah: King Abdul Aziz University, 2008). Retrieved from http://monzer.kahf.com/books/english/fiqhalzakah_vol2.pdf, February 6, 2010.

Bashear, S. "On the Origins and Development of the Meaning of Zakat in Early Islam," Arabica, 40 (1993): 84-113.

Benthall, J. "Financial Worship: The Quranic Injunction to Almsgiving," The Journal of the Royal Anthropological Institute, 5: 1 (1999): 2742.

Berger, I. E. "The Influence of Religion on Philanthropy in Canada," Voluntas: International Journal of Voluntary and Nonprofit Organizations, 17: 2 (2006): 115-132.

Carin, B. and Good, D. A. "Evaluating Efficiency and Effectiveness in Public Sector Delivery," a paper prepared as part of the CEPRA project on Sector and Regional Specifics of Reformation of Budgetary Institutions for the Kaliningrad Workshop, July 24-25 (2004) (retrieved from, http://www.aucc.ca/_pdf/english/programs/cepra/Evaluation_Paper. pdf, February 6, 2010).

Couto, R. A. "The Third Sector and Civil Society: The Case of the "YES" Campaign in Northern Ireland," Voluntas: International Journal of Voluntary and Nonprofit Organizations, 12: 3 (2001): 221-238.

Dompet Dhuafa 2010, retrieved May 20, 2010, from http://www.dompetdhuafa.or.id/

Forum Zakat 2010, retrieved May 20, 2010, from http://forumzakat.net/

Gidron, B. et. al. "Through a New Lens: The Third Sector and Israeli Society," Israel Studies, 8: 1 (2003): 20-59.

Hemment, J. "The Riddle of the Third Sector: Civil Society, International Aid, and NGOs in Russia," Anthropological Quarterly, 77: 2 (2004): 215-241.

Human Appeal International 2010, retrieved May 20, from http://www.humanappeal.org.au/

Jones, E. M. "Building a Future Worthy of Our Past," Foundation: News \& Commentary, 46: 4 (2005) (retrieved from http://www.foundationnews.org/CME/articles.cfm?ID=110\&IssueI $\mathrm{D}=3333$, May 8, 2010). 
Kuran, T. "The Economic System in Contemporary Islamic Thought: Interpretation and Assessment," International Journal of Middle East Studies, 18: 2 (1986): 135-164.

Lohmann, R. A. "Charity, Philanthropy, Public Service, or Enterprise: What Are the Big Questions of Nonprofit Management Today?" Public Administration Review, 67: 3 (2007): 437-444.

McMullen, K. and Schellenberg, G. "Job Quality in Non-profit Organizations," CPRN Research Series on Human Resources in the Non-profit Sector, 2 (2003) (retrieved from http://www.eric.ed.gov/ERICDocs/data/ericdocs2sq1/content_storag e 01/0000019b/80/1b/20/c1.pdf, February 6, 2010).

Payton, R. L. "Philanthropic Values," Philanthropy: Private Means, Public Ends ed. K. W. Thompson. New York: University Press of America, 1987.

(Retrieved from http://webstorage3.mcpa.virginia.edu/publications/mcpapers/rhetori c4.pdf, February 6, 2010).

Pos Keadilan Peduli Ummat 2010, retrieved May 20, 2010, from http://www.pkpu.or.id/

Pierce, L. L. "Philanthropy: A Major Big Business," The Public Opinion Quarterly, 2: 1 (1938): 140-15.

Ranci, C. "Democracy at Work: Social Participation and the 'Third Sector' in Italy," Daedalus, 130: 3 (2001): 73-84.

Ross, A. D. "Organized Philanthropy in an Urban Community," The Canadian Journal of Economics and Political Science, 18: 4 (1952): 474-486.

Rumah Zakat Indonesia 2010, retrieved May 20, 2010, from http://www.rumahzakat.org/

Salim, A. The Shift in Zakat Practice in Indonesia: From Piety to an Islamic Socio-Political-Economic System. Chiang Mai: Silkworm Books, 2008.

" "The Influential Legacy of Dutch Islamic Policy on the Formation of Zakat (alms) Law in Modern Indonesia," Pacific Rim Law \& Policy Journal, 15: 3 (2006): 683-701.

Syamsulhakim, E. "The Effect of the Implementation of the New Regulation on Personal Income Taxation in Indonesia (the Law Number 17/2000) on the Behavioral of Personal Income Tax and Islamic Income Tithe (zakāt al-māl) Payer," Working Paper in Economics and Development Studies, Department of Economics, Padjadjaran University, Bandung, Indonesia (2002). (Retrieved from http://www.equitablepolicy.org/wpaper/200202.pdf, May 20, 2010).

The Synergos Institute. National Directory of Civil Society Resource Organizations: Indonesia. 2002: 1-42. (Retrieved from 
http://www.synergos.org/knowledge/02/indonesiacsrodirectory.pdf, May 20, 2010).

Washburn, W. E. "Philanthropy and the American Indian: The Need for a Model," Ethnohistory, 15: 1 (1968): 43-56.

World Bank. Indonesia at a glance (2009). (Retrieved from http://devdata.worldbank.org/AAG/idn_aag.pdf, May 20, 2010).

Wolpert, J. and Reiner, T. "The Philanthropy Marketplace," Economic Geography, 60: 3 (1984): 197-209.

Zakat Foundation of America 2010, retrieved May 20, 2010, from http://www.zakat.org/ 